\title{
Retroeconomics - Moving from Dying to Brisk Economy
}

\author{
Vladimer Papava*
}

Professor, Faculty of Economics and Business, Ivane Javakhishvili Tbilisi State University, Georgia

\begin{abstract}
The paper offers a new concept of the technological backwardness in many, mostly in poor countries - the retroeconomics. The goal of the research is to set out the main reasons why in many (and first of all in poor) countries the economies used obsolete technologies. Such countries are getting to into the trap of technological dependency on the economically developed countries. The feasible tools for a technological leap from such dependency are discussed. The main threat of the preservation of the retroeconomy - its zombification is discussed as a main barrier for technological updating of economy, and in general as an obstacle for Schumpeterian creative destruction. Much importance is given to the key principle of bankruptcy procedures against zombified retro-firms. The bankruptcy legislation should ensure the timely liquidation of non-viable firms. A country's legislative framework should strive for the establishment of a sound legal space on the market, when only really viable firms will exist. The role of the government is very important to resolve the problem of the technological backwardness.
\end{abstract}

Keywords: Necroeconomy, Zombie-economy, Retroeconomy, Technological Backwardness, Bankruptcy.

\section{INTRODUCTION}

The process of globalization is more or less associated with both the positive and the negative aspects of the economy. Because of the technological backwardness one of the most significant threats to modern economic development is posed by the globalization of a necroeconomy (Papava 2002).

A necroeconomy, or a "dead economy," in its essence, is the supply of goods manufactured using outdated technology for which (goods) there is no demand due to their low quality (or absence thereof) and/or high production costs but where demand is artificially generated by the government (Papava 2002). This ugly economic phenomenon was identified for the purposes of the post-Communist economy since the elimination of competition under the conditions of a command economy wiped out the economic interest to upgrade the technological base in many sectors of the economy (Lipowski 1998) (generally, with the exception of the military-industrial complex). The existence of a necroeconomy prompts the replacement of the market with a quasi-market; one notable example being Ukraine where government expenses to maintain necro-firms are fairly high (Heyets 2015: 12).

A key concept used in the paper is creative destruction, when entrepreneurs' actions create

*Address of correspondence to this author at the Faculty of Economics and Business, Ivane Javakhishvili Tbilisi State University, 1, Ilia Tchavtchavadze Avenue, 0179 Tbilisi, Georgia; Tel: +995-595-33-33-59; Fax: +995-32-298-5265; E-mail: vladimer.papava@tsu.ge

JEL Classification: G33, L26, O38. opportunities for economic development (Schumpeter [1942] 2008). The basic ideas of an evolutionary theory of economic change (Nelson and Winter 1982) are used, as well.

The paper presents a new concept of retroeconomics as a theory of the technological backwardness of an economy and elaborates recommendations how to overcome from the threats of dying of the economies in many countries worldwide.

The paper is structured as follows. In Section 2 the definition of the retreconomy and the factors of its establishment are given. The problem of retroeconomy in a term "technology trap" is discussed in Section 3. In Section 4 the threat of the zombification of retroeconomy and the imperfection of the key principal of the bankruptcy legislation are analyzed. Sections 5 and 6 conclude the paper.

\section{WHY RETROECONOMY?}

It should be emphasized that the technological backwardness of production itself does not constitute a sufficient condition for the emergence of a necroeconomy (it is just a necessary condition); along with technological backwardness, the government should deliberately strive to operate "dead enterprises" by means of generating an artificial demand for their products.

Due to the fact that the restriction of competition is a precondition for the creation of a necroeconomy, it can be concluded that the phenomenon of the 
necroeconomy is present wherever enterprises with technologically obsolete equipment operate solely at the expense of government support. One example of this can be found in the India of the 1980s (OECD 2007). Thus, it appears that a necroeconomy is not only a symptomatic problem for post-Communist countries (as initially indicated in the publications referenced above), but it can be encountered in other countries where enterprises with outdated technology and no real demand for their products operate with government support and, in select cases, entirely at government expense.

The type of economy that fosters the functioning of firms (i.e., retro-firms) that are relatively technologically backward in comparison to contemporary global achievements but where, nevertheless, the demand for their products still exists is referred to as a retroeconomy ("retro" being Latin for "back"). We suggest calling the theory of the technological backwardness of an economy retroeconomics (Papava, 2017).

What are the similarities and differences between a necroeconomy and a retroeconomy? One similarity is that both types of economies make use of outdated technology; the difference is that under necroeconomic conditions, enterprises use equipment so out-of-date that the demand for products they manufacture is virtually nonexistent and, therefore, these enterprises operate solely with government support while in a retroeconomy, the demand for such products does exist and enterprises enjoy only moderate support from the government. In other words, both types of economies require government intervention but while the former exists exclusively at the expense of the government, the latter requires a governmentsanctioned protection of the domestic market from international competition (see below for more details).

What constitutes the building blocks of a retroeconomy? Even though these factors vary in nature, they ultimately result in a single outcome - the establishment of a retroeconomy. In particular, these factors include the following:

I. Protection of intellectual property, which restricts the free dissemination and accessibility of new technological know-how, thus increasing the threat of unauthorized duplication and reengineering of these technologies (Golichenko 2012: 120). Under these circumstances, the authorized use of new technology becomes expensive, especially for firms that operate in poor countries with a relatively low level of economic development. As a result, priority is given to relatively outdated technologies in these particular countries;

II. Monopolization of the economy, wherein monopolies purchase patents on new technologies not for the purpose of applying them in a more or less efficient manner but to prevent third parties from employing them even if the monopolies in question put the patents to use at a later time (or as they deem necessary). By then, it is quite possible that even newer technologies will have been developed, rendering the purchased but idle technology useless (due to moral depreciation). This factor is particularly significant in modern conditions when monopolies have entered a new era (Stiglitz 2016);

III. The behavior of the leading international competitors which, as a rule, do not sell the highest-quality latest-generation technology (Porter 1990: 548). On the contrary, in order to maintain a competitive advantage, they sell already used, second-hand technology (Dementyev 2006), effectively carrying out second-hand investments (Papava 2002: 800). Due to such policies, economically backward countries accumulate not innovative but imitation (or quasi-innovative) technologies (for example, Polterovich and Tonis 2010; Segerstrom 1991) while international competition leaders sidestep morally deteriorating, resource-demanding, labor-intensive and/or environmentally hazardous enterprises, largely promoting the use of the newest technology in the vacated economic space;

IV. Low level of education and an absence of an appropriately educated workforce make it virtually impossible to utilize information even via open channels (not to mention channels of commercial knowledge transfer). This problem is evident in insufficient levels of not only higher and vocational but also secondary education (Golichenko 2012: 118);

V. Zombie economy, signifying a consolidation of firms (and associated banks) rendered insolvent as a result of a financial crisis which continue to operate via bank loans taken on the basis of 
government guarantees (for example, Ahearne and Shinada 2005; Hoshi 2006; LeLaulu 2009). Naturally, zombie-firms have no interest in technological upgrades to manufacturing and/or replacing management since, owing to government support, they manage to maintain operation without these efforts as evidenced, for example, by the Japanese experience (for example, Ahearne and Shinada 2005; Hoshi 2006). It is clear that a zombie economy contributes directly to the establishment of a retroeconomy. At the same time, we should bear in mind that against the background of the global financial crisis of 2007-2009, the globalization of zombie economies (Harman 2010; Onaran 2012; Quiggin 2010), in turn, led to the threat of the zombification of a necroeconomy (where it previously existed) (Papava 2010), the most conspicuous example being Russia's economy (Lindsey 2002: 210-212; Papava 2015).

It is noteworthy that of the five factors listed above, the first four contribute to the formation of a retroeconomy in poor and economically less-developed countries while the fifth factor impacts not only the latter but also those economically developed states.

\section{ON THE "TECHNOLOGY TRAP" AND HOW TO OVERCOME FROM IT}

There is a concept according to which economically backward countries enjoy a certain advantage as compared to developed countries. In particular, at first glance, the viewpoint that the establishment of new technological structures (i.e., a large-scale complex of technologically linked enterprises) in economically backward countries is relatively easier should not be entirely devoid of common sense since the enterprises are not burdened by an excess accumulation of capital corresponding to outdated technological structures (Glazyev 2009: 27). Although, this concept should still be regarded as one-sided since the first, third and fourth factors for the establishment of a retroeconomy listed above preclude economically backward countries from enjoying this advantage (or pseudo-advantage in reality): firstly, a country with few (or, perhaps, no) wealthy firms are virtually unable to afford costly patents on the latest technology; secondly - leading international competitors attempt to obstruct the dissemination of advanced technology; and thirdly the population with inadequate levels of education is virtually incapable of making use of innovative technology.
In highlighting the "advantages of backwardness," as a rule, accent is placed on the possibility for these countries to focus on imitation (quasi-innovation) rather than innovation per se, reproducing already wellestablished technology (certainly, the costs of duplicating technology are clearly less than those of innovation) (Barro and Sala-i-Martin 2004) as a result of which backward countries can minimize the lag (Bresis et.al 1993). It should once again be emphasized that in order for imitation technology to succeed, a properly educated national workforce is an absolute necessity.

Although the retroeconomy established in economically backward countries at the expense of an imitation policy ensures economic growth, imitator countries are under the threat of a long-term maintenance of relatively low levels of productivity as compared to developed countries (Howitt 2000). The principal reason for the differentiation of productivity by country lies in the variance between the type of knowledge applied in each country and the way it is applied (Parente and Prescott 2000).

Focusing on the duplication of relatively outdated foreign technology, provided that other circumstances remain equal, constitutes a mandatory step for economically backward countries which contributes to the preservation of their backwardness as well as the preservation of the retroeconomy thereby driving these countries into the trap of technological dependency (Dementyev 2006).

A "technology trap" is a condition when a firm favors outdated, less-efficient technology, even when the possibility exists to transition to the use of modern technology (Balackij 2003). It is believed that technology traps are triggered when firms give preference to tackling short-term, as opposed to longterm, objectives; the domination of short-term interests over long-term goals is first and foremost due to political, legal and macroeconomic instability (Balackij 2012: 56-57).

We believe that besides the triggers mentioned above, technology traps may be set by a number of other no less significant factors. In particular, as mentioned above, in order for a retroeconomy to exist, government support, albeit moderate, is key. Namely, if a government does not apply protectionist policies in foreign trade, firms equipped with outdated technology will be incapable of competing with leading international competitors furnished with the latest 
technology. According to the evolutionary theory of economic change (Nelson and Winter 1982), so-called "routines" established at retro-firms (i.e., all regular and predictable behavioral patterns of firms which govern the reproduction of the latter's operating characteristics (Murrell 1992)) serve as a basis to presuppose that retro-firms should, first and foremost, endeavor not so much to prepare for engagement in international competition as to expand government protectionist measures in foreign trade, resulting in a lack of effective steps to attract modern technology and driving these firms into technology traps.

Due to the fact that the routine established at retrofirms contributes to a virtually indefinite prolongation of protectionist measures in foreign trade, it is very likely that these firms will gradually transform into zombiefirms (operating via loans taken at the expense of government guarantees) and if circumstances remain unchanged, eventually become necro-firms, the examples of which are emerging in the modern Chinese economy (Lipton 2016).

Hence, there is a close link between technology traps and a retroeconomy: on the one hand, it is evident that a firm placed in a technology trap is essentially a retro-firm; on the other hand, retro-firms in turn contribute to the maintenance of the technology trap.

In order for it to be possible to exit from a retroeconomy and escape the technology trap, a series of complex measures must be put into play.

First and foremost, the government should encourage a sense of economic optimism in society (Balackij 2010) given that under the conditions of a reconciliatory approach to high risk, an optimist seeks to maximize benefits whereas a pessimist attempts to minimize risk in certain acceptable and simultaneously guaranteed terms of benefits (Kessel'man and Mackiewicz 1998). Building a sense of economic sentiment is particularly crucial in countries where, due to political, legal and macroeconomic instability, firms prefer to undertake short-term, rather than long-term, goals (Balackij 2012: 56-57).

In turn, for the purposes of raising the level of economic optimism, great emphasis is placed on the fast-paced growth of the economy as a whole whereas the latter contributes to the creation of such a mental set and when each of the stakeholders operating on the market proceeds to seek high growth rates as well. Under such circumstances, it is very important to make a "technological leap" to avoid technology traps thereby enabling firms to advance to qualitatively newer technology which, in turn, entails expanding access to credit resources, largely dependent on reducing bank interest rates (Balackij 2012: 57). Here, we can only add that, in our opinion, escaping from a retroeconomy, i.e., undertaking a technological leap, suggests that the state shift the spotlight from reducing bank interest rates in general to reducing them only in the case when loans are used to attract modern technology.

We also believe that along with bank loan rate cuts, particular attention should be afforded to the application of tax concessions for firms aiming to utilize modern technology. It should also be emphasized that in preparing for and executing the technological leap, particular significance should be awarded to other measures taken by the government.

As mentioned above, the protection of intellectual property is one of the contributing factors to the maintenance of a retroeconomy, especially in economically backward countries. Because of the protection of intellectual property, advanced technologies remain virtually inaccessible in these countries. Therefore, in our view, on the basis of a country's economic development priorities and an official request filed by firms interested in new technologies, the government should acquire patents on said technologies in accordance with relevant economic sectors in order to facilitate supply to stakeholder firms at reduced prices. This will foster the development of a channel of commercial knowledge transfer, although it can be devoid of potency if not met with a highly-skilled workforce with appropriate knowledge.

The desired result cannot be achieved solely by applying channels of commercial knowledge transfer if the overall level of education cannot furnish the high effectiveness of the open information transfer channel. Thus, one of the key challenges faced by the government is the institution of a general education system which would supply the country's economy with a relevant qualified staff. This entails not only university and vocational but also basic education. The fact that China has gained an advantage over India in terms of economic development can be attributed to the latter placing its main emphasis on university and vocational education and refraining from the creation of a general secondary education whereas China has not spared any effort in advancing all areas of its education sectors (Golichenko 2012: 118). 
A government's undivided focus on the education system serves as the basis for the successful diffusion of technological knowledge (Golichenko 2012).

In order to escape the technology trap, together with the development of the education system, government support for scientific activity is also of great significance since the assimilation and application of new technology is considerably facilitated when a country has its own knowledge production system (Dementyev 2006).

The most compelling threat of the preservation of a retroeconomy and the prolongation of technological entrapment is posed by the zombification of the economy since zombie-firms have no interest in technologically upgrading manufacturing (as well as management) as they manage to operate at government expense. In turn, a zombie economy may transform into a necroeconomy if the process of zombification is so protracted that bank loans taken on the basis of government guarantees prove not to be sufficient. In particular, if the technological base in these firms is not upgraded for an extended period of time, then it becomes so outdated that demand for products manufactured by these firms no longer exists and their preservation solely hinges on the artificial demand generated by the government.

\section{ON THE ZOMBIFIED RETROECONOMY AND THE BANKRUPTCY LEGISLATION}

This situation, at the outset, contradicts the essence of capitalism since the latter, according to Joseph Schumpeter, constitutes a form and method of economic change (Schumpeter [1942] 2008: 82). As is well known, Schumpeter authored the theory of economic dynamics which states that the essence of capitalism lies in the process of "creative destruction," or the process of economic mutation, which virtually continuously demolishes obsolete structures from the inside and replaces them with new ones (Schumpeter [1942] 2008: 83). Creative destruction takes place when the outdated is displaced by the qualitatively new, resulting in the creation of new types of goods, employment of new production methods and the assimilation of new sources of raw materials and new markets. Individuals engaged in these innovative activities, according to Schumpeter, are entrepreneurs whose economic function is to implement innovation (for example, Catner 2016).

A zombified retroeconomy constitutes an obstacle in the process of creative destruction which, if not surmounted, leads to the technological degradation in the economy. According to one view, if the process of creative destruction stalls for a considerable amount of time, it may trigger a collapse of institutions which, by its very nature, is equivalent to a political and military revolution exemplified by the Soviet Union and Serbia (Foster and Kaplan 2001: 294).

It is an unfortunate fact that the preservation of nonviable firms receives active support from various politically and socially influential groups while groups representing the interests of yet unestablished industries or firms do not exist, precisely due to the fact that they (industries, firms) have not yet been established (Anderson 2004: 199). In other words, if non-viable firms have lobbying groups, new industries or firms that have not yet been instituted cannot have similar lobbyists. Under these circumstances, we believe, the only actor potentially able to lobby for new industries or firms to be created is the government.

Much significance is given to the enforcement of bankruptcy procedures against zombified retro-firms. There is admittedly no universal bankruptcy legislation and the key principle typical of bankruptcy regimes is the preservation of the balance between the protection of creditors' interests, on the one hand, and the avoidance of premature liquidation of viable firms, on the other (Stiglitz 2001: 3). In our view, this principle does not fully reflect the challenges facing a modern economy, especially in economically backward poor countries. In particular, the problem is as described below.

A more-or-less objective assessment of a firm's viability is complicated as it calls for a comparison between the going concern value and the liquidation value: if the going concern value exceeds the liquidation value, then the enterprise is viable. The complexity is primarily associated with the determination of the going concern value which entails an evaluation of the future revenues and expenses of an enterprise for which achieving accuracy is not a simple task. This requires the development of a business plan and a reorganization plan for the enterprise. Based on the attitudes of the firm's proprietors, these plans must be optimistic while the perspective of the creditors in terms of the plans is more critical. The estimation of liquidation value is relatively easier, although this process also involves the resolution of several complex tasks (estimation of revenues to be derived from the sale of assets) (Anderson 2004: 175-176). As a result, the decision- 
maker on the form of a firm's bankruptcy, as a rule, leans towards the reorganization, rather than the liquidation, of the enterprise (White 2001: 32). If we recall the circumstances mentioned above, where nonviable firms are actively preserved by various politically and socially influential groups, it becomes clear that zombified retro-firms and, in extreme cases, zombified necro-firms retain their place on the market.

Therefore, in our view, in order to evade the zombification of a retroeconomy or to contribute to creative destruction, the core principle of bankruptcy legislation should change and, in lieu of the above (i.e., the preservation of the balance between the protection of creditors' interests on the one hand, and avoiding the liquidation of viable firms, on the other), a balance must be maintained between the requirement to protect creditors' interests and the need for a timely liquidation of non-viable firms. This approach will improve the competitive environment while competition is the sole basis for firms to generate demand for innovation without which the process of creative destruction, as such, is unfeasible.

Only in the case when the market becomes free from non-viable firms, competition will not only simply force firms to orient themselves towards innovation but also, at the request of relevant entrepreneurs (e.g. Chedi, 2015), politicians and government officials will be obligated to support their (entrepreneurs') interests through decision-making.

Based on international experience, it is believed that, especially in poor countries, the settlement of the issue of an insolvent firm's viability, first and foremost, should take place via a direct agreement between the creditors and the firm's proprietors while government intervention as per bankruptcy law should occur in the case when creditors and proprietors are unable to reach an agreement (Anderson 2004: 176-178).

It is noteworthy that in the maintenance and development of viable firms on the market, focusing solely on bankruptcy law is unjustified as the latter is rather significant but still one of several pieces in a country's legislative framework which, together with other laws, should strive for the establishment of a sound legal space on the market (White 2001: 43). For instance, if a country, in addition to its bankruptcy laws, also has legislation that governs the restructuring of tax debts, then the latter virtually blocks the initiation of bankruptcy procedures.

\section{CONCLUSIONS}

In many, and mostly in poor countries the economies used obsolete technologies. As a result all these countries have retroeconomy. The factors establishing of the retroeconomy are: protection of intellectual property, monopolization of the economy, the behavior of the leading international competitors (which, as a rule, do not sell the highest-quality latestgeneration technology), low level of education, zombie economy. The technologically backward in comparison to contemporary global achievements constitutes a mandatory step which contributes to the preservation of the retroeconomy thereby driving these countries into the trap of technological dependency.

A zombified retroeconomy constitutes barriers in the creative destruction process. The key principle of any bankruptcy regimes is the preservation of the balance between the protection of creditors' interests, on the one hand, and the avoidance of premature liquidation of viable firms, on the other. The principle does not reflect the problem of the existence of the retroeconomy and it should be changed.

The phenomenon of a retroeconomy is already quite deep-rooted throughout the world and it is essential to consolidate the attention of economists and politicians on this threat in order to preclude the zombification of a retroeconomy, not to mention its transformation into a necroeconomy.

\section{RECOMMENDATIONS}

It can be concluded that for the purposes of overcoming a retroeconomy, particular emphasis is given to a government's economic policy which, certainly, may not be one-dimensional. Expressly:

1. The government must spare no effort in the development of the education system which implies the improvement of the quality of the general secondary education and the harmonization of vocational and university education with international standards;

2. The government should see the support of scientific activity as the core component of the improvement of university education; given the country's economic development potential, the government must define priority areas based on which relevant scientific groups should be funded to implement pertinent research projects; 
3. The government should establish channels of commercial knowledge transfer for the purposes of which, in accordance with the country's key economic development priorities, and in response to an official request lodged by firms, the government should acquire patents on technology in keeping with relevant economic sectors to then supply these firms at reduced prices;

4. In order to attract modern technology, the government should render assistance to relevant firms to cover part of the bank interest and also offer tax concessions;

5. In order to promote the process of creative destruction, the government should ensure to the maximum extent possible that no non-viable firms remain on the market which, first and foremost, should occur via the establishment of an adequate legislative framework. National bankruptcy laws should rely on a basic principle which states that a balance should be maintained between the interests of the creditors, on the one hand, and the timely liquidation of non-viable firms, on the other;

6. It is recommended that the issue of the viability of insolvent firms be addressed through a direct agreement between the creditors and the proprietors of a firm while the government intervene in the process citing bankruptcy law only in the case when the two sides are unable to reach an agreement;

7. The government should establish a sound legal space on the market which excludes other laws and regulations impeding the efficient application of bankruptcy law.

It should be taken into account that in imposing these functions on the government, when there is a real threat of failure and, especially, when state institutions are weak and the corruption level is high (Dompe 2014), great significance is afforded to publicizing the decisions to be taken by the government in order to ensure maximum public and expert engagement in the development of these decisions.

\section{REFERENCES}

Ahearne, Alan G. and Naoki Shinada. 2005. "Zombie Firms and Economic Stagnation in Japan." International Economics and Economic Policy 2(4): 363-381. https://doi.org/10.1007/s10368-005-0041-1
Anderson, Robert E. 2004. Get Out of the Way: How Government Can Help Business in Poor Countries. Washington, D.C.: CATO Institute.

Balackij, Evgenii V. 2003. "Ekonomicheskij rost i tekhnologicheskie lovushki [Economic Growth and Technological Traps]." Obshchestvo i ekonomika [Society and Economy] 11: 53-76. (In Russian.)

Balackij, Evgenii V. 2010. "Rol' optimizma v innovatsionnom razvitii ekonomiki [The Role of Optimism in the Innovative Development of the Economy]." Obshchestvo i ekonomika [Society and Economy] 1: 3-20. (In Russian.)

Balackij, Evgenii V. 2012. "Institutsional'nye i tekhnologicheskie lovushki [Institutional and Technological Traps]." Zhurnal ekonomicheskoij teorii [Journal of Economic Theory] 2: 4863. (In Russian.)

Barro, Robert J. and Xavier Sala-i-Martin. 2004. Economic Growth. Cambridge, MA: MIT Press.

Bresis, Elise S., Paul R. Krugman, and Danial Tsiddon. 1993. "Leapfrogging in International Competition: A Theory of Cycles in National Technological Leadership." American Economic Review 83(5): 1211-1219.

Catner, Uwe. 2016. "Foundations of Economic Change - an Extended Schumpeterian Approach." Journal of Evolutionary Economics 26(4): 701-736. https://doi.org/10.1007/s00191-016-0479-z

Chedi, Mariem. K. E. 2015. "Entrepreneurial Features of the Creators of Innovative Enterprises." International Journal of Economic Practices and Theories 5(3): 213-221.

Dementyev, Victor E. 2006. "Lovushka tekhnologicheskikh zaimstvovanij i usloviya ee preodoleniya $v$ dvukhsektornoij modeli ekonomiki [A Trap of Technological Adoption and the Terms to Overcome it in the Two-Sectors Economic Model]." Ekonomika i matematicheskie metody [Economics and Mathematical Methods] 42(4): 17-32. (In Russian.)

Dompe, Stewart. 2014. "Industrial Policy Is Still a Loser." Mises Daily Articles, July 16. Available from: https://mises.org/library/ industrial-policy-still-loser [accessed July 21, 2017].

Foster, Richard and Sarah Kaplan. (2001). Creative Destruction: Why Companies that are Built to Last Underperform the Market and How to Successfully Transform Them. New York: Currency.

Glazyev, Sergei. 2009. "Mirovoij ekonomicheskij krizis kak protsess smeny tekhnologicheskikh ukladov [World Economic Crisis as a Process of Substitution Technological Models]." Voprosy ekonomiki [Issues of the Economy] 3: 26-38. (In Russian.)

Golichenko, Oleg. 2012. "Modeli razvitiya, osnovannogo na diffuzii tekhnologij [Models of Development Based on Technology Diffusion]." Voprosy ekonomiki [Issues of the Economy] 4: 117-131. (In Russian.)

Harman, Chris. 2010. Zombie Capitalism. Global Crisis and the Relevance of Marx. Chicago: Haymarket Books.

Heyets, Valerii M. 2015. "Preodolenie kvazirinochnosti - put' k investitsionno orientirovannoij modeli ekonomicheskogo rosta [Overcoming the Quasimarketness - a Way to the Investment-Oriented Model of Economic Growth]." Ekonomika Ukrainy [Economy of Ukraine] 6: 4-17. (In Russian.)

Hoshi, Takeo. 2006. "Economics of the Living Dead." The Japanese Economic Review 57(1): 30-49. https://doi.org/10.1111/j.1468-5876.2006.00354.x

Howitt, Peter. 2000. "Endogenous Growth and Cross-Country Income Differences." The American Economic Review 90(4): 829-846. https://doi.org/10.1257/aer.90.4.829

Kessel'man, Leonid E., and Marija G. Matskevich. 1998. "Ekonomicheskij optimizm/pessimizm v transformiruyushchemsya obshchestve [Economic Optimism/Pessimism in a Transforming Society]." Available 
from: http://www.nir.ru/sj/sj/12kesel.htm [accessed July 21, 2017]. (In Russian.)

LeLaulu, Lelei. 2009. "Zombie Economics?" The Development Executive Group, 13 January. Available from: http://www.devex.com/articles/zombie-economics [accessed July 21, 2017].

Lindsey, Brink. 2002. Against the Dead Hand: The Uncertain Struggle for Global Capitalism. New York: John Wiley \& Sons.

Lipowski, Adam. 1998. Towards Normality. Overcoming the Heritage of Central Planning Economy in Poland in 1990-1994. Warsaw: Adam Smith Research Center, Center for Social and Economic Research.

Lipton, David. 2016. "China's Corporate-Debt Challenge." Project Syndicate, August 18. Available from: https://www.projectsyndicate.org/commentary/china-corporate-debt-problem-bydavid-lipton-2016-08 [accessed July 21, 2017].

Murrell, Peter. 1992. "Evolution in Economics and in the Economic Reform of the Centrally Planned Economies." Pp. 35-53 in The Emergence of Market Economies in Eastern Europe, edited by C. Clauge, and G.C. Rausser. Cambidge, MA. \& Oxford, UK: Blackwell Publishers.

Nelson, Richard R., and Sidney G. Winter. 1982. An Evolutionary Theory of Economic Change. Cambridge, MA: Belknap Press of Harvard University Press.

OECD. 2007. OECD Economic Surveys: India. Available from: http://www.keepeek.com/Digital-Asset-

Management/oecd/economics/oecd-economic-surveys-india2007_eco_surveys-ind-2007-en\#.V7F969R95kg\#page1 [accessed July 21, 2017].

Onaran, Yalman. 2012. Zombie Banks. How Broken Banks and Debtor Nations are Crippling the Global Economy. Hoboken, $\mathrm{NJ}$ : John Wiley \& Sons. https://doi.org/10.1002/9781119202707

Papava, Vladimer. 2002. "Necroeconomics - The Theory of PostCommunist Transformation of an Economy." International Journal of Social Economics 29(9-10): 796-805. https://doi.org/10.1108/03068290210444421

Papava, Vladimer. 2010. "The Problem of Zombification of the Postcommunist Necroeconomy." Problems of Economic Transition 53(4): 35-51. https://doi.org/10.2753/PET1061-1991530403
Papava, Vladimer. 2015. "Necroeconomics of Post-Soviet PostIndustrialism and the Model of Economic Development of Georgia and Russia." Journal of Business and Economics 6(5): $976-983$. https://doi.org/10.15341/jbe(2155-7950)/05.06.2015/012

Papava, Vladimer. 2017. "Retroeconomics - Global Challenge for Economic Development." The Market Oracle, February 9. Available from: http://www.marketoracle.co.uk/Article58104. html [accessed July 21, 2017].

Parente, Stephen L., and Edward C. Prescott. 2000. Barriers to Riches. Cambridge, MA: MIT Press.

Polterovich, Victor, and Alexander Tonis. 2010. "Innovation and Imitation at Various Stages of Development: A Model with Capital." MPRA Paper No. 20244, January 26. Available from: https://mpra.ub.uni-muenchen.de/20244/2/MPRA_ paper_20244.pdf [accessed July 21, 2017].

Porter, Michael E. 1990. The Competitive Advantage of Nations. New York: The Free Press. https://doi.org/10.1007/978-1-349-11336-1

Quiggin, John. 2010. Zombie Economics. How Dead Ideas Still Walk Among Us. Princeton, NJ: Princeton University Press.

Schumpeter, Joseph A. [1942] 2008. Capitalism, Socialism, and Democracy. New York: Harper Perennial Modern Thought.

Segerstrom, Paul S. 1991. "Innovation, Imitation, and Economic Growth." Journal of Political Economy 99(4): 807-827. https://doi.org/10.1086/261779

Stiglitz, Joseph E. 2001. "Bankruptcy Laws: Basic Economic Principles." Pp. 1-23 in Resolution of Financial Distress: An International Perspective on the Design of Bankruptcy Laws, edited by S. Claessens, S. Djankov, and A. Mody. Washington, D.C.: The World Bank. https://doi.org/10.1596/0-8213-4906-6

Stiglitz, Joseph E. 2016. "Monopoly's New Era." Project Syndicate, May 13. Available from: https://www.projectsyndicate.org/commentary/high-monopoly-profits-persist-inmarkets-by-joseph-e--stiglitz-2016-05?barrier=true [accessed July 21,2017$]$.

White, Michelle J. 2001). "Bankruptcy Procedures in Countries Undergoing Financial Crises." Pp. 25-45 in Resolution of Financial Distress: An International Perspective on the Design of Bankruptcy Laws, edited by S. Claessens, S. Djankov, and A. Mody. Washington, D.C.: The World Bank.

Received on 21-07-2017

Accepted on 11-08-2017

Published on 31-08-2017

\section{DOI: https://doi.org/10.6000/1929-7092.2017.06.46}

(C) 2017 Vladimer Papava; Licensee Lifescience Global.

This is an open access article licensed under the terms of the Creative Commons Attribution Non-Commercial License (http://creativecommons.org/licenses/by-nc/3.0/) which permits unrestricted, non-commercial use, distribution and reproduction in any medium, provided the work is properly cited. 